$\bar{I} Q \bar{A} N:$ Vol:01, Issue:01, Dec 2018

\title{
CRITICAL APPROACH TO PERCEPTIONS OF BERNARD LEWIS REGARDING ISLAMIC POLITICAL \& SOCIAL PRACTICES.
}

\author{
Dr. Inam Ullah Wattoo \\ Assistant Professor, Department of Islamic Studies, \\ Cholistan university of veterinary $\mathcal{E}$ animal Sciences,Bahawalpur.

\begin{abstract}
Abida Naseem
Assistant Professor, Department of Islamic Studies,

Govt. Degree College for Women, Malikwal, Mandi bahaudin.
\end{abstract}

\begin{abstract}
$\underline{\text { Abstract }}$
Bernard Lewis is a representative scholar of eastern studies and western thoughts, and he is the most influential political figure in the U.S politics. So his thoughts play an important and vital role in academic and political fields of the West. Most of his writings explore his prejudiced attitude toward Islam and Muslims. He wrote many books about the teachings of Islam. Islam being a universal religion is an interesting topic for western intelligentsia like Lewis. There are many institutes of Islamic studies in their universities and many think tanks are working on various aspects of Islamic teaching for multiple purposes. In some educational institutions of the west revisionist orientalists such as Andrew Rippin are teaching Islamic thoughts from a critical and revisionist perspective which is quite contrary to the traditional Islamic teachings. Bernard Lewis is attached with The RAND cooperation (the most influential think tank of U.S.A) and most of his writings are evident of his prejudiced theories about political and social practices of Muslims.
\end{abstract}

Keywords: Bernard Lewis, western thoughts, political practices, social systems.

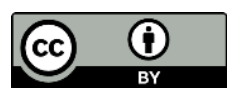


A Critical Approach on Perceptions of Bernard Lewis

Regarding Islamic Political \& Social Practices

\section{Introduction:}

Bernard Lewis is a prominent person among the western thinkers of this century. He has a great participation in research about religions, but in spite of his great knowledge and vision of religion, he is an open example of western prejudiced attitude toward Islam and the Muslims. He wrote many books and articles relating to the various aspects of the Islam yet his always vindictive behavior. In this article we examine critically his vision.

He is a most prominent orientalist. He is much interested in Middle Eastern Studies and political activities of the Muslim world. He was born on May 31, 1916 in Stoke Newington, London. He belongs to a Jewish family. He is a British-American scholar of history especially interested in oriental studies. In 1936 he graduated from the School of Oriental Studies (SOAS) at the University of London with a B.A. in history with unique reference to the Near and Middle East. In 1939 he earned his Ph.D. in history of Ottoman also from SOAS. ${ }^{1}$

It is frequently propagated that Islam and the West are two competitors in political domination and civilization. In $7^{\text {th }}$ century it was Islam, which destroyed the non-Muslim political domination in Byzantine and elsewhere. After centuries, Islam was defeated by Christian Crusaders. Now it is suggested in western world that Islam is a permanent danger for the West and Europe, if Europeans want to maintain their political supremacy in the world politics, they should crush the Islamic values and views. Therefore, now a major portion of western academia specially those who are interested in Middle Eastern Studies, Bernard Lewis is a wellknown figure in this concern. They continuously write and express in seminars and conferences, that Islam is a danger for western civilization and western political domination.

\section{Islamic believes about Prophets of the Past and their teachings:}

In the history of religions, Islam is not a new religion or faith but this is a complete, secured and final edition of God's Laws revealed on the prophets of the past. These collections of revealed teachings on the prophets of the past were also called Islam and those who recognized these teachings

${ }^{1}$ https://en.wikipedia.org/wiki/Bernard_Lewis, (accessed 12 Dec, 2018) 
were also called Muslims. Details about these are not described in any book of the world, it is the only honor of the Holy Quran that it provides enough guidance and knowledge about the important matters of human life. Islam was the only religion from the beginning to the end of prophethood. This is not narrated in any revealed or historical books except Holy Quran. ${ }^{1}$

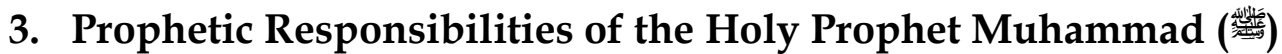

Within appointing the last Prophet, in the Holy Quran Allah explained that $\mathrm{i}$ am going to provide guidance for all mankind by you. So these teachings and laws are connected to the series of Prophet hood. All these were also revealed on the prophets of the past. As the Holy Quran stated:

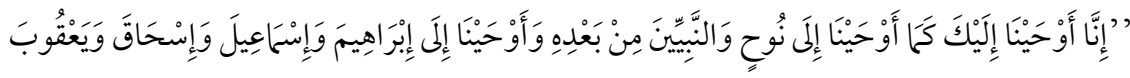

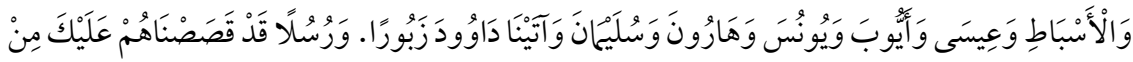

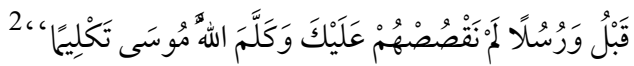

4. Teachings of Noah (God be pleased with him)

Describing further details, the Holy Quran said that Noah (علي السلام) was the first among the prophets who were send toward polytheist nations. He invited them toward Islam and declared them Muslim with these words.

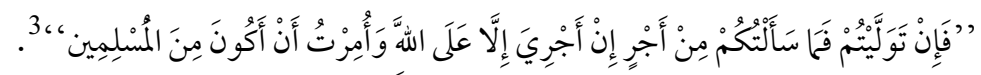

5. Teachings of Ibrahim (God be pleased with him)

The teaching of Ibrahim (God be pleased with him) were also the teachings of Islam. The Holy Quran said that Ibrahim (God be pleased with him) was a Muslim and advised his generations/ Sons /children to remain Muslims till the end of life. The Holy Quran stated:

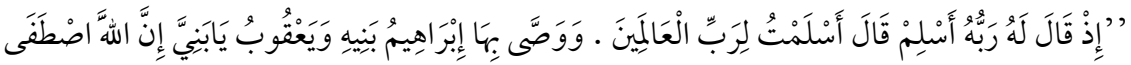

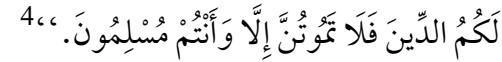

1 Subject related to many thoughts.

2 Al-Nisa: 163-164 (Translation of the Qur'an is used throughout by “The Holy Quran - English Translation of the Meaning and Commentary: By Abdullah Yusuf Ali and IFTA")

${ }^{3}$ Younus: 72

${ }^{4}$ Al-Baqara: 131-132 
A Critical Approach on Perceptions of Bernard Lewis

Regarding Islamic Political \& Social Practices

6. Teachings of Musa (God be pleased with him)

Musa (God be pleased with him) was a prominent prophet among the prophets of Bani Israel. About him the Holy Quran stated that they were Muslims and the followers of Islam and their nation was also Muslim:

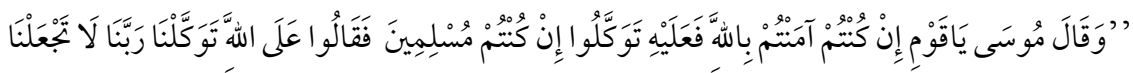

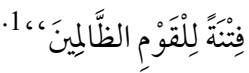

The Holy Quran also described that Pharos, the ruler of Egypt, refused to accept the prophetic teachings of Hazrat Musa (علي السلام) but when he and his army was ruining in the river and that time he announced himself to be Muslim, as the Holy Quran stated:

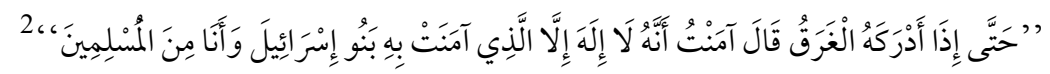

\section{Teachings of 'Îsā (God be pleased with him)}

In this chain the last prophet of Bani Israel Jesus's (God be pleased with him) massage and teachings are also mentioned in the Holy Quran. It is also narrated that when he asked his companions to bring faith then they also declared to be Muslim and bring faith:

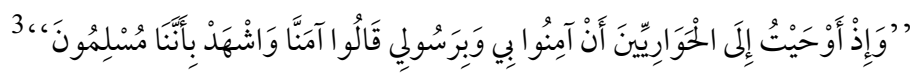

Above mentioned details proved that every past messenger was the Prophet of Islam and all the followers of those were not Christian, Jews or Hindu but they were called Muslims.

The Holy Quran stated that these terminologies were formed by the people after them. This statement of the Holy Quran is also verified by the New Testament. As in the chapter Act, it is mentioned that Bernabas in the search of Sawl visited a town named Tarsus, here they both preached the religion of Jesus (God be pleased with him), and meanwhile preaching in the town named Antakya, first time they used the terminology of Christian.

\footnotetext{
${ }^{1}$ Younus: $84-85$

${ }^{2}$ Younus: 90

${ }^{3}$ Al-Maida: 11
} 
"Then departed Bernabas to Tansus for to seek Soul........they assembled themselves with the church and taught much people and the disciples were called Christian fir in Antiock." ${ }^{1}$

\section{Role of Prophets in the development of human society}

Personality of the Prophet is a central point of a religion/faith. Allah Himself selected his prophets then revealed on them his laws/rules. On the base of these rules Prophet is responsible for the development of individual life in morality and all other aspects of social life. Worship, rule of law or the establishment of a society has developed with the struggle, teachings and trainings of the prophet. From the beginning, Allah is responsible for providing the laws to construct the different aspects of human life. So, the Holy Quran mentioned it and stated that when Allah sent Adam and Satan in this world. Allah said that I will send you rules/laws for your guidance and prosperity for permanent life (After life). The Holy Quran stated:

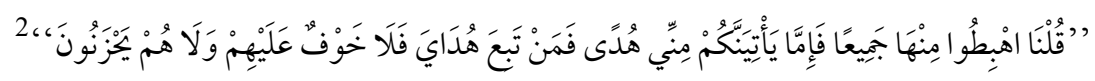

This statement is very logical and fulfils the requirements of human mentality that if the creator of life will provide the guidance for spending life then life will be constructed on right ways. After His responsibility, the Lord of the Universe appointed the prophets. From obedience and morality in individual's personal life to the rule of law and establishment of state in the light of these rules and laws are the duties of the Prophets. So, it is mentioned in the Holy Quran and the duties/ responsibilities of Prophecy are described in this way:

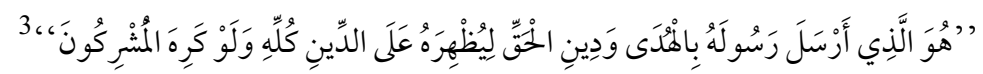

Meanings of the above-mentioned verses showed that some rebels of the Lord of Universe will create a society by their own desires in worldly activities. Destruction of such systems, creation and development of a society according to the rules of God will be the responsibility of these Prophets. That's why that these prophets were stood stand before the rulers of Time to express the rule of Allah.

${ }^{1}$ New Testament, Act: 11: 25-26

2 Al-Baqara: 38

${ }^{3}$ Al-Saff: 09 
A Critical Approach on Perceptions of Bernard Lewis

Regarding Islamic Political \& Social Practices

Ibrahim (God be pleased with him) against Hammurabi (Namrood), Musa (God be pleased with him) against Pharo and Prophet Muhammad (SAW) against Abu Jahal was the result of these prophetic responsibilities. Simple description of these all details make it very easy to understand for a common man.

\section{Logics behind the appointments of Prophets}

Creator of the life deserves the rights to provide guidance for the proper and accurate use of life. Others are not eligible to do so. If the creator or the Lord of Universe approaches to individuals and tells him his will and way for life.

Then it will be impossible to create a society of United in thought and actions. If the Lord of Universe do this then every individual will understand his massage according to his mental ability which will also make it impossible to create a society with United in thought and actions.

When for this purpose Allah appointed prophets then Prophets are not alike a post man to deliver his massage to his creation. But it is the duty of a prophet to make the rule of laws understandable for human mind by his advises, to develop their individual character by His own individual character, by his collective character as a leader of society to teach them the rules of collective morality. Then also Allah keeps this responsibility with Him to send messengers and Prophets to every society and nations, so that I make them answerable at the Day of Judgment.

When the Prophets of different era and different nations have same center, same purpose, same method of teaching and preaching then similarity in the massage of these all prophets is very natural matter.

\section{Western Illusion}

It is very sadness aspect of western civilization that the writers and thinkers of their society in spite to understand this very simple demand of human nature for completion of the purpose of the creator they involve the human societies in the Clashes of civilizations and made the man enemy of man. 
If a person interested in religions, he should keep in mind the basic elements of the study of religions. Many contradictions among religions can easily be solved. This is a positive way of thinking for the plural society.

\section{Political System of Islam}

Bernard Lewis is a representative scholar of eastern studies and western thoughts, and his thoughts play an important and vital role in academic and political field of the west. About the political system of Islam, he stated that Islamic political system based on the basic concept of divine guidance of the Holy Quran and the traditions of the Prophet Muhammad (SAW).

As Prophet was appointed by God to explain the massage of God and to guide the community. According to the Holy Quran Allah is the Sovereign of state, and this belief is prevailed in the text of all Muslim writers too, so Bernard Lewis expresses that:

"In the Muslim view the ultimate repository of sovereignty was

God, from whom the Prophet derived both his authority and his law."1

It is the religious duty of all Muslims to obey Allah, His apostle and the ruler of the Islamic state:

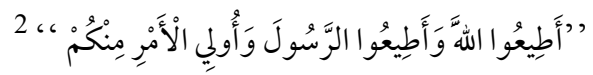

According to prophetic traditions, the Ruler of the Islamic state should be well aware about the political, social and religious affairs of state and Justice:

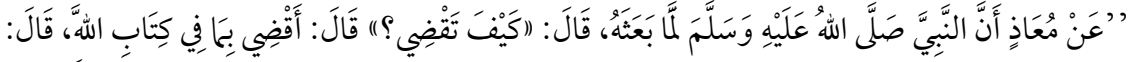

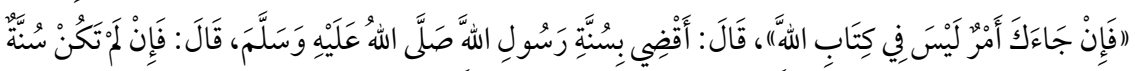

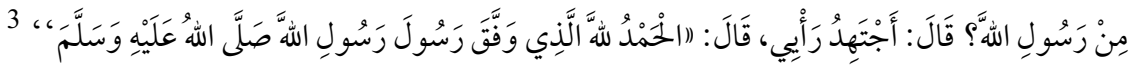

Islam was involved in politics from its beginning as he argues and discussed many of its logics through the Medinan state and historical

\footnotetext{
${ }^{1}$ Lewis, Bernard, The world of Islam, Faith, People, Culture, (London: Thames and Hudson, 1980), p:12.

${ }^{2}$ Al-Nisa : 59

${ }^{3}$ Ibn e abi Shebah, Abdullah bin Muhammad, Al-Mussanaf, (Al-Riyadh: Al-Rushd publisher, 1409 AH), Vol: 2, P:543
} 
A Critical Approach on Perceptions of Bernard Lewis

Regarding Islamic Political \& Social Practices

backgrounds. In his book, "Islam from Prophet Muhammad to the Capture of Constantinople" he wrote that Muslims holy prophet (SAW) proved himself as a great magistrate, as he says:

"Islam was thus involved with political power from the start. Medina was a state and, as it turned out, the nucleus of an empire with the Prophet as its first magistrate."

\section{State and Religion:}

Allah almighty is the creator and sustainer of the Universe. He is the only Lord of the whole Universe. A man uses all his sources to gain political Sovereignty. In Islamic State, this Sovereign power is not in the hands of human. The prominent advantage of this political system is that there is no tyranny, injustice, abolishing of individual rights and inequality. In this system rulers and subject admitted the Sovereignty of Allah almighty and perform their duties with honest. As Allah almighty said in the Holy Quran:

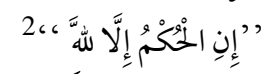

This Quranic verse shows that in Islamic state Allah is only sovereign power, ruler of the state is not authorized to alter the divine laws, he is only responsible to take measure for the implementation of Sharia,

All the political system of the world have a sovereign power in their political system, as it is the sovereign of a state which maintain and provide the laws for running a state in fair ways. In different systems there are different concepts of sovereignty, as in Christianity, there is no evidence of God's Sovereign power. Unlike Christianity in Islam there is a clear concept of God sovereignty:

"Jesus had instructed the Christians to render unto Caesar the thing which are Caesar's and unto God the things which are God's."

And he said:

\footnotetext{
${ }^{1}$ Lewis, Bernard, Islam from Prophet Muhammad to the Capture of Constantinople, (U.S.A: The Macmillan press Ltd, 1974), p: xvi

${ }^{2}$ Yousuf: 40

${ }^{3}$ Lewis, The world of Islam, Faith People Culture, p:12
} 
"In Rome, Caesar was God; in Christendom God and Caesar shared power. In Islam, God is Caesar, and the head of the Muslim community is His vicegerent on earth." 1

In Christian views state and religion are two different institutes with different duties. But in Islam matters of state are consulted and maintained with the guidance of religion. Political theory of Islam is based on the fundamental teachings of the Holy Quran and the traditions of the Holy Prophet (SAW).

The Prophet Muhammad (SAW), was not only a prophet but a leader of the state in His life time, His prophetic and political actions are saved for the guidance of after him. According to Lewis in His life time at the same time He (SAW) was a religious leader and head of the Islamic community, but He did not leave any clear instruction for the selection of religious and political leader of the community:

"Muhammad had however left no reasonable guideline in the matter of who was to succeed him." 2

Although Muhammad (SAW) did not left any clear instruction for the selection of Caliph yet there was a tradition of consultation to solve the disputed matters in Islamic society. So, the Companions of Muhammad (SAW) following this patron for the selection of Caliph.

Bernard Lewis in his book "the political language of Islam" discussed about the political system of the west and Islam and put his words that unlike Christianity in Islam there was no distinction between religion and political authorities. As he wrote:

"In classical Islam there were no distinction between church and state." 3

At the same page he expresses that the idea of separation of state and Church is derived from Christianity:

"In pre-westernized Islam, there were not two powers but rather one, and the subject of partition, consequently, couldn't emerge."

\footnotetext{
${ }^{1}$ Lewis, The world of Islam, Faith People Culture, p:12

${ }^{2}$ Ibid

${ }^{3}$ Bernard Lewis, The political language of Islam (Chicago: The University of Chicago press, 1988), p:2

${ }^{4}$ The political language of Islam, $\mathrm{p}: 2$
} 
A Critical Approach on Perceptions of Bernard Lewis

Regarding Islamic Political \& Social Practices

For ruling a state there is required a law upon which a state established its solidity and stability. In Islamic state, law of state is derived from the Holy Quran and the Sunna, more over the examples of early period of pious Caliphs. So, it is the basic duty of a Caliph to maintain and insure the Islamic law in state and community:

"This law is not limited to the matter of belief, ritual and religious practice; it deals also with criminal and constitutional matters, with family and inheritance" 1

The stability of state is based upon the law and law enforcement institutions. But every state has its own law and law-making institutions. In Islamic state there is only one law called sharia. It is the duty of Muslim ruler to ensure that Islamic state is successfully working under the banner of Islam and law of state is not contrary to Sharia, and government of Islamic state is trying to spread Islam and its law. In this scenario Quran says:

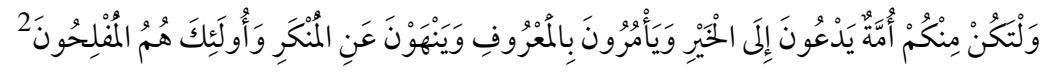

"And that there might grow out of you a community [of people] who invite unto all that is good, and enjoin the doing of what is right and forbid the doing of what is wrong: and it is they, they who shall attain to happy state."

\section{The Islamic political identity:}

Lewis expressed his views about Islam and other religions and wrote constantly in his books and papers that the people of Islam instead of having different form/types of government, they share common thoughts as they organized international groups as in united nation and elsewhere. There are more than 40 Islamic countries with different ruling types. Some of them are the supporters of Western Block, others are of Eastern Block, but they together are constituting so-

Called Islamic Block for their religious political identity:

"This (so-called Islamic Bloc) includes monarchies and republics, conservative a radical, exponents of capitalism and of socialism,

\footnotetext{
${ }^{1}$ The world of Islam, Faith, People, Culture, p:31

${ }^{2} \mathrm{Al}$ e Imran: 104
} 
supporters of the western Bloc, of the Eastern Bloc, and of a whole spectrum of shades of neutrality. They have built up and elaborate apparatus of international consultation and, on many issues, cooperation; they hold regular high-level conferences, and despite differences of structure, ideology, and policy, they have achieved a significant measure of agreement and common action. In this the Islamic peoples are in sharp contrast with those who profess other religions." 1

As now in recent era Muslim world is facing many challenges, Muslims in different part of the world are worst victim of political injustice. Kashmir, Palestine, Iraq and Iran are in war status, number of innocent Muslim have killed and injured in these wars. Problem of Kashmir is a hot topic of this era.

It is very important to dominant that United Nation is totally failed to provide political rights and freedom, history of United Nations forum cleared that this forum is only for the promotions and defense of Some powers. So, in this situation, Muslim have no other option except forming Muslim Block.

\section{Major revolutions in history:}

According to Bernard Lewis there were many major revolutions in the world as French and Russian revolution but Iranian revolution was a different revolution which threaten the whole world. It was a religious development, which occupied with a Struggle against agnosticism, persecution the domain to restore a genuine Islamic order:

"In 1979 a series of events began in Iran which brought profound

change not only in the government but also in the whole society of

the country, with

consequences reaching far beyond the Iranian frontiers." ${ }^{2}$

According to Lewis, unlike Iranian revolution it was not religion but liberty, equality and fraternity which caused French revolution:

\footnotetext{
${ }^{1}$ The political language of Islam, $\mathrm{p}: 3$

${ }^{2}$ Ibid
} 
A Critical Approach on Perceptions of Bernard Lewis

Regarding Islamic Political \& Social Practices

"The French Revolution, with its ideological backgrounds in the eighteenth-century Enlightenment its ideals as liberty, equality, fraternity." 1

The Russian revolution was also a major revolution of human history, it was socialism which caused this huge revolution:

"The Russian revolution, with a background in nineteenth-century socialism, set forth its plan for the future in terms of a classless state to be achieved through a dictatorship of the proletariat." ${ }^{2}$

Iranian revolution was based on Islam to restore true Islamic order:

"The Iranian revolution presents itself in terms of Islam, that is to say, as a religious movement with a religious leadership, a religiously formulated critique of the old order, and religiously expressed plans for the new."

Bernard Lewis stated that Iranian revolution was the greatest revolution of the history which has had effected the political system of the world:

"The Iranian revolution too has had an enormous impact all over the world with which it shares a common general and political culture. The culture is defined by Islam." 4

\section{Islam was not spread by sword or force:}

It is a widespread view in the West that Islam was spread by sword or force. Although it was not true yet Western and European writers continuously insisted on it for a long time. But now the writers of modern era such as John Esposito, John $\mathrm{O}$ wall and many others admitted that it was not force but conquest and colonization of Islam which caused the spread of Islam in other societies:

"It has sometimes said that the Islamic religion was imposed by force. This is not true, though the spread of both Islam and Arabism

\footnotetext{
${ }^{1}$ The political language of Islam, $\mathrm{p}: 3$

2 Ibid

${ }^{3}$ Ibid

${ }^{4}$ Ibid, p:2
} 
was to a large extent made possible by the parallel process of conquest and colonization."

According to Muslim belief it is the duty of every Muslim to preach Islam in every situation. There are no special missionaries, but it is a simple duty of every Muslim assigned by the Holy Quran to bring the faith to the unbelievers.

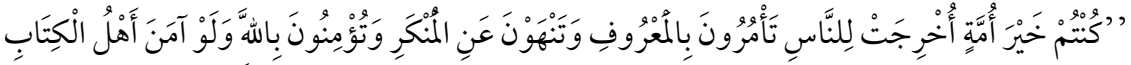

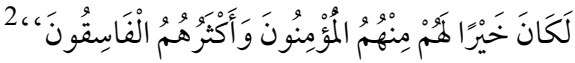

But at the same time, it is strictly forbidden for the men of other religions in Muslim state to convert a Muslim to any other religion:

"It is the duty of a Muslim, wherever he may be, to bring the faith to the unbelievers. Islam unlike Christian, has no missionaries but assigns this task to all Muslim alike."3

From the beginning of Islam, Islam and Christianity were always in conflict. In $7^{\text {th }}$ century Muslim warriors entered in Christian lands and corporate the Christian lands in Islam. Majority of Christians embraced Islam, others were free to act upon their own religion. As their matter related to their religion were solved according to their religious teachings by their religious leaders. They were not compelled to convert, even at the time of Muslim triumph over Christianity, they were free in their choice. Three options were offered to them. First, convert to Islam, second pay poll tax, third ready to fought and die ${ }^{4}$.

After centuries, Christians were in war field against Muslims to reconquer their holy lands from Muslims. It was announced that those who will join this adventure, will be in paradise if martyr, otherwise there will be great economic and financial benefits for them:

"The Crusaders are the best known of the various invaders who entered the Islamic world in the middle Ages. For more important, however, from the

\footnotetext{
${ }^{1}$ The world of Islam, Faith, People, Culture, p:14

${ }^{2} \mathrm{Al}$ e Imran: 110

${ }^{3}$ Bernard Lewis Islam and the West, (London: Oxford University press, 1993), p:53.

${ }^{4}$ Ahmad Bin Hambal, Abu Abdullah Ahmad bin Muhammad, Musnad Ahmad bin Hambal, (Beruit: Moassasah Al-Risalah, 1995) Vol: 38, P: 78
} 
A Critical Approach on Perceptions of Bernard Lewis

Regarding Islamic Political \& Social Practices

Islamic point of view was the coming of the steppe people from the north."

He blamed on the Muslims and Islamic teachings that to spread Islam they used power as wars and Jihad. In contrast with these ethnically defined and geographically limited civilizations, Islam was on a fundamental level widespread in its convictions, its self-observation, and its aspirations in whole world, for example Indonesia, India, Pakistan, Bangladesh, Nigeria. ${ }^{2}$

"The Muslim believed himself to be the fortunate possessor of God's

final revelation and saw it as his duty and his privilege to bring God's truth to the rest of mankind, if necessary, by jihad, by war "in the path of God." ${ }^{3}$

16. Social inequalities in Islamic society and Islamic teachings:

With everything considered there was far more prominent social portability in Islam than was allowed either in Christian Europe or Hindu India. This balance of status and opportunity was constrained in certain imperative regards. The rank of a full individual from society was confined to a free male Muslim. The individuals who did not have any of these key capabilities - that is, the slaves, the lady, or the unbeliever - were not equivalent:

A real distinction between the three is the component of decision:

"A woman cannot choose to become a man. A slave can be freed, but by the choice of his master, not his own. Both the woman and the slave are thus in a position of involuntary----for the woman also immutable----inferiority. Inferiority of the unbeliever, however, is entirely optional and he can end it at any time by a simple act of will. By adopting Islam he becomes a member of the dominant community, and his status of legal inferiority is at an end."

\footnotetext{
${ }^{1}$ The world of Islam, Faith People Culture, p:15.

2 See Pew's research

${ }^{3}$ Bernard Lewis, Cultures in Conflict, Christian, Muslims, and Jews in the age of discovery, (New York: Oxford University press, 1995), p:9.

${ }^{4}$ Bernard Lewis, The Jews of Islam (U.S.A: Princeton University press, 1984), p:9.
} 
This is a false imagination of western scholars that there are social inequalities in Islamic society. All the citizens are equal in their status but their duties are different according to their eligibility. In Islamic society male members are the responsible for the maintenance of their families and women are responsible for the training and education of their children. Both are equal before God:

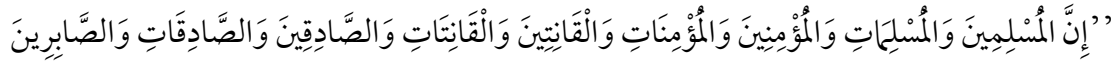

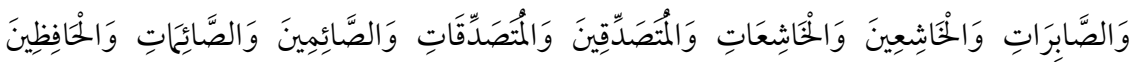

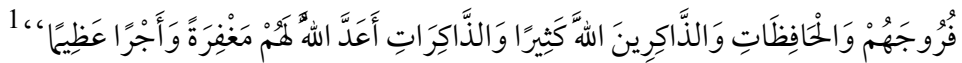

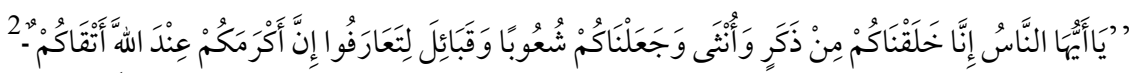

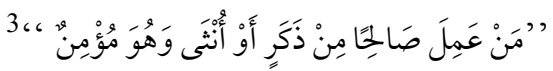

Above mentioned Quranic verses clearly show the importance, status and equality of women in Islamic society. Difference in their duties is the natural demand for the survival of human family system. If both mother and father neglect family life and adopt professions for earning than who will be the responsible for the training of next generation. As Dr. Mahar-ul-Nisa writes in her book "Khandan aur Bradari ki Nashonuma" (flourishing of Clans and family):

"Economically, members of a family depend upon each other to fulfil

their necessities. Especially the guardian, guidance and physical stability of children is the moral and economic responsibility of their Parents" $^{\prime 4}$

Difference of their duties is natural according to their physical appearance. A man can work hard than a woman. Man can wage wars against enemies but woman cannot. So, these are not inequalities but these are different duties for different members of the society according to their capability.

It is universal habit of human societies to divide people into insiders

\footnotetext{
${ }^{1}$ Al-Ahzaab :35

${ }^{2}$ Al-hujuraat :13

${ }^{3}$ Al-Nahl :97

${ }^{4}$ Ahmad, Mahar-ul-Nisa, Khandan aur Brathri ki Nashonuma (Karachi: NBF, 1988), p:7
} 
A Critical Approach on Perceptions of Bernard Lewis

Regarding Islamic Political \& Social Practices

and outsiders, and to find opprobrious names for the later, the two most self-conscious people antiquities called the rest gentiles and Barbarians:

"Medieval Islam and Christendom called each other infidels;"

The unbelievers are subdivided, in most Muslim theoretical discussions of the subject, by two broad classifications, one theological, the other political:

"The theological classification is between those who follow a monotheistic religion based on revelation, and those who do not." 2

This classification was for their recognition. There were no different symbols for Ahl-e-Kitab and polytheistic followers. All were called dhimmi. Both were equal in Islamic society, as the Holy Prophet (SAW) stated:

"Someone who unjustly kills a dhimmi (person under protection) cannot get a whiff of Heaven. However, its fragrance is felt from a distance of forty years". 3

$$
\text { أنا أحق من وفى بالذمة4 }
$$

Islam does not emphasize on the Muslims to wage a war against all the non-Muslims of the world. It is very clear that all the states wage a war against those to whom it considered its enemy. Just like this Islam wages a war against those non-Muslims who remain contrary to Islam and try to create instability in Islamic state and society. If they want to live in peaceful manners, the Holy Quran advices the Muslims to create peaceful atmosphere.

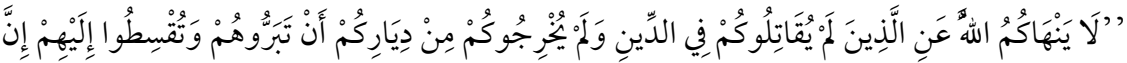

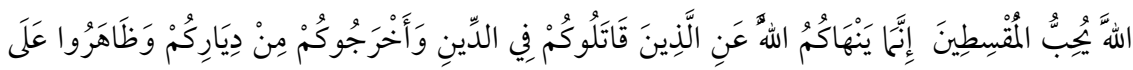

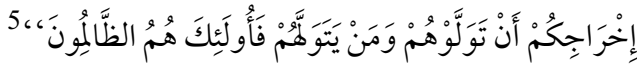

\footnotetext{
${ }^{1}$ Bernard Lewis, The Middle East and the West (London: Weidenfled and Nicolson, 1964), p:70

${ }^{2}$ The Jews of Islam, p:120.

3 Bukhārī, Muhammad bin Ismāīl, Al-Jāme al- sahih, (Al-Riyadh: Dar us salam, 2004), H: 3166

${ }^{4}$ Ibn e abi shebah, Al-Mussanaf, Vol: $5, p: 40$

${ }^{5}$ Al-Mumtahina : 8-9
} 
$\bar{I} Q \bar{A} N:$ Vol:01, Issue:01, Dec 2018

He says:

"Christianity was vanquished, not annihilated by the ascent of Islam and the foundation of the Islamic state. In any case, the procedures of Arab settlement, of change to Islam and absorption to the overwhelming society, gradually reduced the Christianity---when and at what stage is impossible to say----from a majority of a minority of the population." ${ }^{1}$

Now many Western scholars like John Esposito, John O, wall and many others admitted the fact, that Islam was not spread by force or sword. As in above mentioned paragraph, he said that majority of non-Muslims was convert to Islam, and it is impossible to say, that when and how they convert. It shows that it was the authenticity of Islam that non-Muslims observe Islam and embrace it as religion.

"For the greater part of the history of both communities, tolerance was not valued nor was intolerance condemned. Until comparatively modern times, Christian Europe neither prized not practiced tolerance itself, nor was not greatly offended by its absence in others." 2

According to their own statement Christian Europe neither prized not practiced tolerance itself. Contrary to this Islam have great tolerance for other religions as there are rights of non-Muslim minorities in Muslim state and society. They are free to practice on their religion. They are not compelled to convert. Allah almighty said in the Holy Quran:

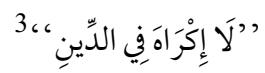

"There is no compulsion in Faith".

The Non-Muslims in the Muslim state are so safe that the Apostle of Allah advised the Muslims to treat well with them. Allah and his Apostle are the responsible for the security of dhimmi.

"For the pagan the choice was clear: Islam or death. For Jews and Christians, possessors of what were recognized as revealed religions, based on authentic though superseded revelations, the choice

${ }^{1}$ The Jews of Islam, $\mathrm{p}: 17$

${ }^{2}$ The Jews of Islam, $\mathrm{p}: 3$

${ }^{3}$ Al-Baqara :256 
A Critical Approach on Perceptions of Bernard Lewis

Regarding Islamic Political \& Social Practices

included a third term: Islam, death or submission, submission

involved the payment of tribute and the acceptance of Muslim

supremacy. Death might be commuted to slavery." ${ }^{1}$

He blamed this on Islam without any reference and evidence. Islam treats equally with all other religions. If this is true he should must be present or add some authentic evidence. All the conquered subjects were offered to embrace Islam or admit submission or ready for fight ${ }^{2}$. As in war, it was not allowed to murder those who were not a part of that war, as women, children and old age non-Muslim were safe in battles.

As to live in Islamic empire by paying poll tax, mean they have recognized the realization and superiority of original Islamic law, When Islam was dominated So the possibility of circumcision is over. Therefore, the battle will now be stopped, now minorities will have all the rights in the Islamic Empire which have a Muslim. As the Allah said in the Holy Quran:

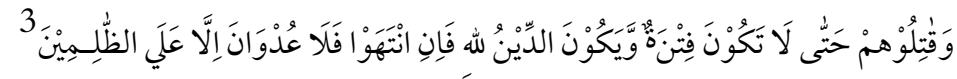

"Fight them until there is no Fitnah any more, and obedience remains for Allah. But, if they desist, then aggression is not allowed except against the transgressors".

This Holy verse shows that termination of extremism and disturbance is end of war. the total number of wars in the Period of Holy Prophet is 86 , and even if it considered aggressive wars than also total number of murders in all these wars is 1018 and dividing this digit on 86, we found that average killing ratio in these wars is 12.414 . Total number of war prisoners is 6564 and surprisingly, among this number 6000 prisoner are of War of Hunain and they all were released.

Comparative to this only two world wars are worst example of genocides of human. The number of murders and injured person is greater than $700,00,0$. The burden of the poll tax, and more particularly the way of

\footnotetext{
${ }^{1}$ The Jews of Islam, p:10

2 Al-Baheiqi, Abu Bakr Ahmad bin Al-Husain, Al-Sunan al Kubrā, (Beruit: Dar ul Kutab alilmia 2003), Vol: 9, P: 310

${ }^{3}$ Al-Baqra: 193
} 
$\bar{I} Q \bar{A} N:$ Vol:01, Issue:01, Dec 2018

its instalment. It should be brought from them with belittlement and mortification:

"He the (dhimmi, i.e., the non-Muslim subject of the Muslim state)

should come in individual, strolling not riding, when he pays, he

might stand, while the duty authority sits, the gatherer should seize

him by the neck's scruff, shake him, and say: 'pay Jizya!', and when

he pays it he should be slapped on the scruff of his neck." 1

Jizya collected by non-Muslims was a great source of income for Muslim state. This was paid for the security of their lives and property. Dhimmis were treated in well manners, they were free in their religious practice. Muslim rulers treated justly with dhimmis of Muslim states. One of its examples is narrated in history books of Islam that Umar (God be pleased with him) took much care for dhimmis. Once an old Jew was in hard labor for earning, he asked the reason of this hard labor in old age. He replied, I am working hard to pay Jizya. After this incident, Umar (God be pleased with him) issued an order to exempt the Jizya of old aged nonMuslims ${ }^{2}$.

\section{Influence of Jews on religious literature:}

Religious literature was subject to strong Christian and Jewish influence, especially in the early period, and much apocalyptic and Talmudic material was incorporated into the traditions:

"Theological literature proper began under the influences of Syrian Christianity, later also of Greek thought."3

It is against the fact that Talmudic material was incorporated into the traditions of the Holy Prophet (SAW). The Muslims have scientific methodology for the authenticity of Ahadith. A large number of Mohadithins (Scholars of Ahadith science) devoted their lives in this struggle. Very soon, the theologians of Islam separated the Jewish material from the origins. There are permanent sciences for the principles of Ahadīth. As Ilm-e-Asmāa-o-Rījāl and Ilm-e-Jarh wal-T'adīl. ${ }^{4}$ Through this

\footnotetext{
${ }^{1}$ The Jews of Islam, p:12

${ }^{2}$ Abu Yousaf, Yaqob bin Ibrahim, Kitab ul Khiraj, (Cairo: Al-Matbah al-salfiah, 1963), P: 1-3

${ }^{3}$ The Arabs In History, p:136

${ }^{4}$ Mehmood Tehan, Teiseer Mustaleh-ul-hadith, (al-riyad : Maktabah al-muarif, 1996) p: 83
} 
A Critical Approach on Perceptions of Bernard Lewis

Regarding Islamic Political \& Social Practices

science Muslim theologians separate the invented traditions from original traditions.

\section{Islam as triple threat:}

Islam's portrayal as a triple threat political, civilization, and demographic has been amplified by various writers and researchers who trivialize the multifaceted nature of political, social and religious element in the Muslim world.

"West of Iran and the Arabian Peninsula, the vast majority of the earliest converts to Islam in the Levant and North Africa were converts form Christianity. This process of conversion continued in the Muslim-ruled lands of Sicily and Spain." ${ }^{1}$

"For most Muslim writers, Christendom - first Byzantine and then European - was the House of War par excellence. ${ }^{2}$

He warns the west, that if Muslim immigration continued, very soon Muslims will occupy the west as they did in past with Byzantine ${ }^{3}$. Now Europe is the target for Muslims. For Muslims Byzantine was the House of war, they triumphed over it. Now Europe is the House of war for them and they will repeat the history with it.

\section{Muslims under non-Muslim state:}

Lewis argues that a Muslim traveler cannot visit the land of infidels. Moreover, it is not permissioned for a Muslim to live in the land which are under Christian control. The topic of a Muslim explorer to the unbelievers' terrains for a willful or automatic, brief or extended visit was of more pragmatic concern and gets more consideration.

"The Moroccan law specialist Ahmad al-Wansharisi, writing in the last phase of the Christian re-triumph of Spain, demands that regardless of the possibility that the Christian vanquishers are both just and endure, the Muslim are still required to leave - to be sure, much all the more along these lines, subsequent to under such an administration the threat of abandonment would be correspondingly

\footnotetext{
${ }^{1}$ Cultures in Conflict, Christian, Muslims, and Jews in the age of discovery, p:12

${ }^{2}$ The Arabs In History, p:14

${ }^{3}$ Islam and the West, p:66
} 
$\bar{I} Q \bar{A} N:$ Vol:01, Issue:01, Dec 2018

more prominent." 1

This statement is quite contrary to the facts. Muslims are not restricted to live in non-Muslim states, especially under Christian controlled governments. It shows that writer is quite unaware about the history of Islam. As first migration in Islamic history was toward Habsha (Ethiopia), a Christian land ruled by a Christina ruler Najashi. Moreover, it is the religious obligation of all Muslims to call the people for Islam which is not possible without travelling in non-Muslim lands. Holy Prophet (SAW) also sent his companions to many heads of states for calling them to Islam as like Abyssinia, Egypt, Syria, Bahrain. ${ }^{2}$

\section{The question of marriage with non-Muslim:}

He objected on the Muslim family law in which a male Muslim is permitted to marriage with a non-Muslim lady, however a Muslim lady is not allowed to wed a non-Muslim man:

"On this point the legal scholars are consistent-a Muslim man may wed a non-Muslim lady, however a non-Muslim man may not, on agony of death, wed a Muslim lady. In marriage, so the law specialists trusted, the spouse is dependably the predominant accomplice." 3

Every civilization have right to make rules for its society. As male members in Islamic society are dominant power in domestic affairs. So, it is expected that a non-Muslim wife soon or later embrace the Islam.

In case if a Muslim woman married a non-Muslim man. Chances of embracing Islam reduced. Therefore, Islam did not allow Muslim women to wed with a non-Muslim male. Also, Quran declared Men have authority on Women:

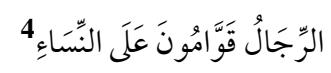

Men are caretakers of women

\section{Muhammad (is a complete model for all human:}

A fundamental, recognizing component of Islam is the sweeping

\footnotetext{
${ }^{1}$ Islam and the West , p:52

2 For detail see: ibn ul qayyīm, Zad al-Ma 'ad, (beruit: dar ul-fikr, 2010) V:2, p:24

${ }^{3}$ Islam and the West , p:53

${ }^{4}$ Al Nisa: 34
} 
A Critical Approach on Perceptions of Bernard Lewis

Regarding Islamic Political \& Social Practices

character of religion in the impression of Muslim. The Holy Prophet (SAW), not at all like prior originators of religions, established and represented a commonwealth:

"As ruler, he promulgated laws, dispensed justice, commanded armies, made wars, made peace, collect taxes, and did all other things that a ruler does. This is reflected in the Quran itself, in the biography of the prophet, and in the traditions concerning his life and work." ${ }^{1}$

Muhammad, like Jesus, was the founder of a great world religion. Unlike Jesus, he achieved worldly success in his own lifetime. At first, he too, like other Prophets, was a humble, persecuted teacher and preacher. But instead of martyrdom he attains power.

In Mecca he had a proscribed critic of the existing order; in Medina he created his own order. As head of the Ummah, the community of his converted and adherents, he administered, apportioned equity, gathered charges, and made peace and war. In Mecca he preached only, but in Medina he practiced his divine teachings:

"in Median he practiced. The scope of his revelation was extended from religious and moral principles to a wide range of mundane matters; its form changed from precept to law. This is clearly reflected in the Quran." ${ }^{2}$

Some intelligentsia of the west also did not like this one-sided way of thinking of Bernard Lewis. As an American well-known orientalist Edward Said discussed 9/11 incident and its impact on world politics in the preface of his world-famous book "Orientalism" and wrote about the

negative and illiteracy attitude of Lewis.

"it is surely one of the intellectual catastrophes of history that an imperialist war confected by a small group of unelected US officials was waged against a divested third world on thoroughly ideological ground having to do with world dominance--the major influence on

\footnotetext{
${ }^{1}$ The Multiple Identities of the Middle East, p:27

${ }^{2}$ Islam form Prophet Muhammad to the Capture of Constantinople, p:xv-xvi
} 
$\bar{I} Q \bar{A} N:$ Vol:01, Issue:01, Dec 2018

Gorge W Bush Pentagon and national security council were men such as Bernard Lewis"1

\section{Conclusion:}

Bernard Lewis is a prominent person among the western thinkers of this century, He is a most prominent orientalist. He is much interested in Middle Eastern Studies and political activities of the Muslim world. It is frequently propagated that Islam and the West are two competitors in political domination its own law- and law-making institutions. In Islamic state there is only one law called sharia. It is the duty of Muslim ruler to ensure that Islamic state and civilization. In $7^{\text {th }}$ century it was Islam, which destroyed the non-Muslim political domination in Byzantine and elsewhere. In the history of religions, Islam is not a new religion or faith but this is a complete, secured and final edition of God's Laws revealed on the prophets of the past. These collections of revealed teachings on the prophets of the past were also called Islam and those who recognized these teachings were also called Muslims. Personality of the Prophet is a central point of a religion/faith. Allah himself selected his prophets then revealed on them his laws/rules. It is very sadness aspect of western civilization that the writers and thinkers of their society in spite to understand this very simple demand of human nature for completion of the purpose of the creator they involve the human societies in the Clashes of civilizations and made the man enemy of man. The stability of state is based upon the law and law enforcement institutions. But every state has is successfully working under the banner of Islam and law of state is not contrary to Sharia, and government of Islamic state is trying to spread Islam and its rules.

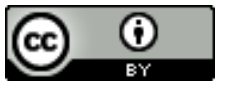

This work is licensed under a

Creative Commons Attribution 4.0 International License.

${ }^{1}$ Edward Said, Orientalism (New York :Vintage books, 1994, 25 ${ }^{\text {th }}$ Addition), p: xx 